\title{
A.JOГ一
}

African Journal of Teacher Education

ISSN 1916-7822. A Journal of Spread Corporation

Volume $92020 \quad$ Pages $21-48$

\section{The Influence of Locus of Control, Study Habits and Gender on the Academic Achievement of Senior Secondary School Physics Students in Ibadan Metropolis}

\author{
Uchenna Kingsley Okeke \& Edidiong E. Ukoh \\ Department of Science and Technology Education, \\ University of Ibadan, Nigeria.
}

\begin{abstract}
The study investigated the relationship between Locus of Control, Study Habit, Gender and Academic Achievement of senior secondary school physics students in Ibadan metropolis. The descriptive survey research design was adopted. Seven hundred and fifty senior secondary two (SS2) Physics students were randomly selected from 30 schools in the five local Governments areas of Ibadan Metropolis. Three instruments were used for data collection. The instruments are Physics Achievement Test (PAT) $(r=0.70)$, Locus of Control Scale (LOCS) (0.86) and Study Habit Questionnaire (SHQ) (0.89). Two (2) research questions were answered, using inferential statistics of t-test, and multiple regression analysis. Findings of the study showed that there is a relationship between locus of control and Academic Achievement [r=0.216, $n=750, p=<0.01]$. It was found that Locus of Control, Study Habits and Gender predicted students' academic achievement of Students, with $R=0.203$, which is equivalent to $20.3 \%$. This however indicates a poor level of prediction. $R^{2}=0.041$, which is equivalent to $4.1 \%$, indicating a very poor level of shared variance between the dependent variable and the independent variables. The study recommends the adoption of the instructional methods that will enhance students' locus of control and the promotion of good study habits among senior secondary school physics students. Governments, education administrators, and school authorities should consider the joint interactive influence of locus of control, study habits and gender when designing programs for physics.
\end{abstract}

Keywords: Locus of Control, Study Habits, Gender, Academic Achievement 


\section{Introduction}

The importance of physics as a requirement for understanding the intricacies of modern technology and its essential contribution to technological advancement cannot be overemphasized. Physics is the connection between science and technology. Physics is the branch of science that deals with objects, energy and their interactions. Physics principles are used by technologists to fabricate devices and gadgets that people use in all spheres of human endeavour like in medicine, telecommunication, military, transportation, just to mention a few. Any country that desires technological advancement must take the teaching and learning of physics very seriously. Sani (2012) noted that the study of Physics can lead students onto diverse scientific fields and professions such as engineering, manufacturing, mining and construction industries. Hence, the immense benefit of Physics to the development of the society.

According to Nigerian Education Research and Development Council (NERDC, 2008), the objectives of senior secondary school physics curriculum is:

to provide basic literacy in physics for functional living in the society, acquire basic concepts and principles of physics as a preparation for future studies, acquire essential scientific skills and attitudes as a preparation for technological application of physics; and stimulate and enhance creativity.

As laudable as these objectives are, achieving them have been difficult over time. Nigerian students' performance in physics in external and certificate examinations has been a source of worry to stakeholders of education. Below is a table displaying Nigerian students' performance in May/June West African Secondary School Certificate Examinations from 2006 to 2017.

Table 1: Statistics for entries and result for May/June WASSCE Physics from 2006-2017

\begin{tabular}{|l|l|l|c|c|c|}
\hline Year & No of & Credit & Pass & Fail 9\% & Total Fail \\
& Candidates & $(1-6)$ in \% & $(7-8)$ in \% & & \\
\hline 2006 & 375824 & 58.05 & 23.15 & 16.52 & 39.67 \\
\hline 2007 & 418593 & 43.19 & 33.48 & 21.13 & 54.61 \\
\hline
\end{tabular}


The Influence of Locus of Control, Study Habits and Gender on the Academic Achievement of Senior Secondary School Physics Students in Ibadan Metropolis

\begin{tabular}{|l|l|l|c|c|c|}
\hline 2008 & 415113 & 48.26 & 21.95 & 28.13 & 50.08 \\
\hline 2009 & 465636 & 47.83 & 30.41 & 17.16 & 47.57 \\
\hline 2010 & 463755 & 51.27 & 26.40 & 18.27 & 44.67 \\
\hline 2011 & 563161 & 63.94 & 24.30 & 11.76 & 36.06 \\
\hline 2012 & 624658 & 68.74 & 22.06 & 09.20 & 31.26 \\
\hline 2013 & 636857 & 46.62 & 27.62 & 22.92 & 50.54 \\
\hline 2014 & 644391 & 60.21 & 24.83 & 12.58 & 37.41 \\
\hline 2015 & 605248 & 40.02 & 25.36 & 34.62 & 59.98 \\
\hline 2016 & 666901 & 76.27 & 16.05 & 5.52 & 21.57 \\
\hline 2017 & 704504 & 53.10 & 27.43 & 17.40 & 44.83 \\
\hline
\end{tabular}

Source: Statistics Section, West African Examinations Council (WAEC) National Office, Onipanu, Lagos, Nigeria

Table 1 above illustrates fluctuations in the outcome of secondary school certificate examination in Physics between 2006 and 2017. In 2006, 58.05\% of the applicants who sat for Physics examination recorded a minimum of credit pass in the examination; in 2007, 2008 and 2009, 43.19\%, 48.26\% and 47.83\% respectively recorded a minimum of credit pass in Physics, indicating a decline from the result recorded in 2006. However, the results of 2010 (51.27\%), 2011 (63.94\%) and 2012 (68.74\%) showed a steady increase. This was then followed by a sharp decline in 2013 at a cumulative pass percentage of $46.62 \%$. The performance of students in the 2014 WASSCE showed an improvement from the previous year with a cumulative pass percentage of $60.21 \%$, again followed by a sharp decline in 2015 to $40.02 \%$. The pattern was repeated for 2016 and 2017 results, with the 2016 result posting a steep improvement value of $76 \%$ success rate and a subsequent drop to $53 \%$ in 2017. 
Fig 1: Percentage pass recorded in May/June WASSCE Physics from 2006-2017

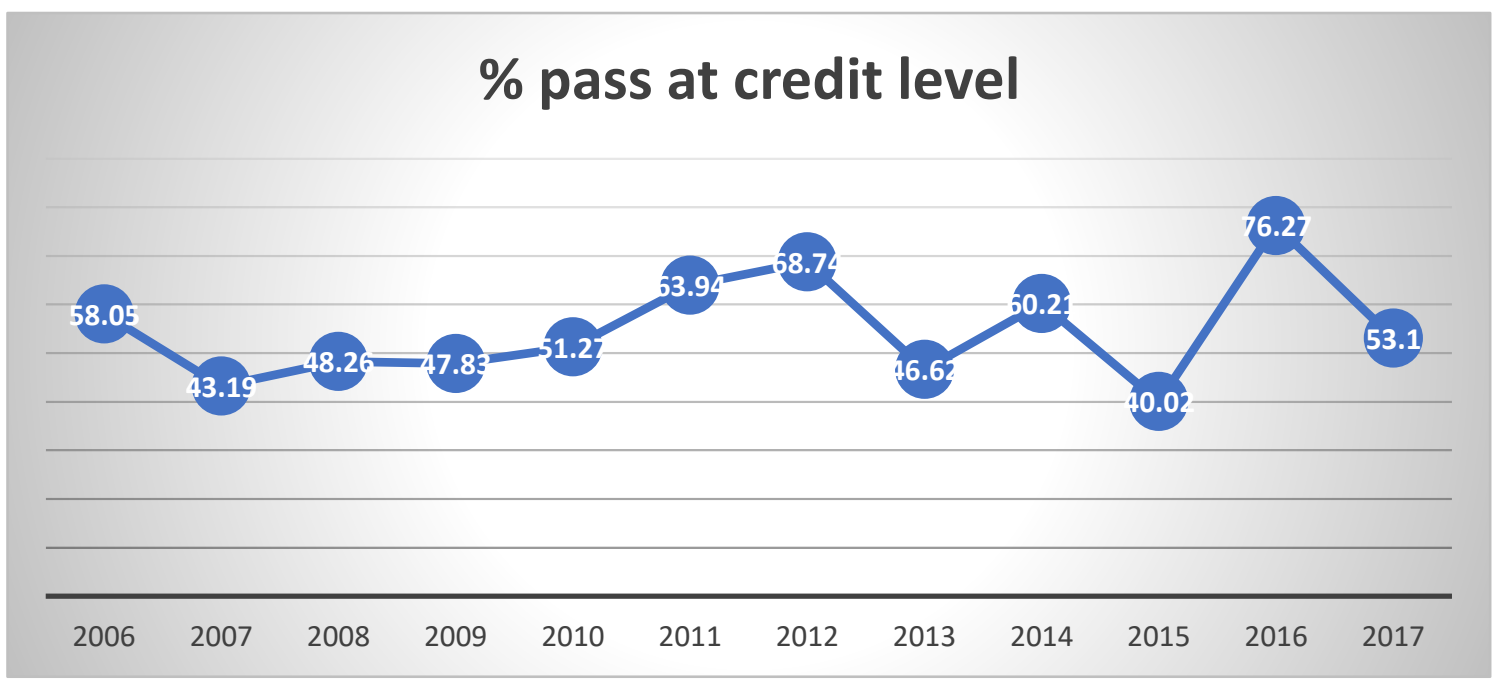

These fluctuation in students' performance as demonstrated in the figure above is worrisome and requires attention.

The mastery of a subject is determined by the performance of the students in such a subject at a prescribed examination. The expectation for teacher-students interactivity is a successful outcome for learners. The expectation for students' academic achievement occupies a central position in the educational process. Academic achievement, frequently measured by the examination results, is considered a key criterion in the evaluation of one's potentialities and capacities (Nuthana and Yenagi 2009). Hence, the fluctuating performance of Nigerian students in Physics has been a major source of concern to science educators. Several factors that have been identified to be responsible for this poor academic achievement of students in Physics include students' Locus of control, study habit, and gender.

\section{Locus of Control}

The concept of Locus of control was developed by psychologist Julian Rotter in 1954 (see Fakeye (2011). His suggestion was that human behaviour is controlled by both punishments and rewards. Consequences stemming from an individual's actions would then influence the perception of the causes of the events and actions. The concept was further refined in 1966 when Julian Rotter created and published a scale that measures whether an individual's locus of control is internal or external. Locus 
The Influence of Locus of Control, Study Habits and Gender on the Academic Achievement of Senior Secondary School Physics Students in Ibadan Metropolis

of control can be defined as the strength of an individual's belief in the amount of control that they have over life-affecting situations and experiences. Individuals have varied opinions about who and what controls their life. Some attributes the outcome of their endeavours to gods, luck or another person, while some will attribute the outcome of their endeavours to their own effort and experiences (Ogunmakin and Akomolafe, 2013).

Individuals who possess an internal locus of control typically assume that they possess a degree of control over circumstances and events that happen to them. However, individuals who possess an external locus of control believe that they have no control of what happens to them, which leads them to place responsibility and blame on external variables such as luck and gods. A student who records poor performance in Physics may ascribe his performance to the abstract nature of the subject, inadequate resource availability, or poor teaching method adopted by the teacher. A student may say that it is of no need to study for a class test since he will still fail the test because the teacher does not like him. Such student will not work harder or learn from previous experiences. These beliefs show his locus of control.

Fakeye (2011) carried out a study on locus of control as a correlate of academic achievement of students in English as a second language in Ibadan. He shows that learners who have internal locus of control orientation believes that their aptitude are guided by their personal decisions and efforts while learners with external locus of control orientation believe that their aptitude is girded by fate, luck or external circumstances. Research reveals that students who have moderate to strong internal locus of control perform better. The place of the locus of control in learning is very important because all things being equal, people will either see themselves as masters of their destiny or victims of circumstances. In learning situation, internal orientation needs to be accomplished by competence, self-efficacy and opportunity. Awofala, Awofala, Fatade and Nneji (2012) argued that possession of internal locus of control is essential for students to have a thorough understanding of science and mathematics. According to them, these students are more likely to develop an intrinsic orientation in which participation in science and mathematics tasks brings them feelings of competence, mastery, control and self-determination. In summary, individuals with internal locus of control are reported to

engage in activities that will improve their situation; emphasize striving for achievement; work hard to develop their knowledge, skills and abilities; are inquisitive, and try to figure out why things turned out the way they did; take note of information that they can use to create positive 
outcomes in the future; have a more participative management style; manage the drawbacks of a strong Internal Locus of Control and, are generally more successful (Awofala, Awofala, Fatade and Nneji, 2012).

Individuals with external locus of control are said to lack competence, self-efficacy, and can become neurotic, anxious and depressed. They tend to be more stressed and prone to clinical depression, according to Tucker. People who are over-dependent on external factors for motivation, are said to be more likely to become agitated when these factors are absent Hamayan, and Genesse (2006). Awofala et al (2012) concluded that external locus of control makes people vulnerable to manipulation and open to abuse since such people would depend largely on the reinforcement by significant others for everything they do. Conversely, those with internal locus of control are more at peace with themselves and they take responsibility for their mistakes and successes. It is believed that students develop internal locus of control as they grow. Students with internal locus of control tend to have good study habits.

Significant relationship between locus of control and academic achievement of students have been reported by various studies (Awofala et al 2012; Akinleke and Adeaga 2014). A study of Orang Asli students in Malaysia by Azlina, Ma'rof, Hanina and Mohd Ibrani (2015) indicates that the internal locus of control is significantly associated with good academic performance, while external locus of control related to low academic performance. This means that the achievements of students in Physics may be moderated by the extent to which students attribute success or failure to internal or external factors, i.e., factors under or not under their control.

Contrarily, findings of studies conducted by Reynolds and Weigand (2010), Dinçyürek, Güneyli, and Çaglar (2012) and Oludipe (2013) found no significant relationship between locus of control and academic achievement of students. These findings offered a contrary position to the views of studies which found significant relationship between locus of control and students' academic achievement. Other similar contrary findings include those by Omotayo (2012) cited in Oludipe (2013), which revealed that locus of control did not significantly predict $(\mathrm{R} 2=0.017 \mathrm{p}>0.05)$ students' achievement in Economics. Ogunmakin and Akomolafe's (2013) study of academic self-efficacy, locus of control and academic performance of secondary school students in Ondo State, Nigeria concluded that locus of control was not able to predict students' performance. However, locus of control and academic self- 
The Influence of Locus of Control, Study Habits and Gender on the Academic Achievement of Senior Secondary School Physics Students in Ibadan Metropolis

efficacy, when jointly considered, was able to predict students' performance. This finding could be interpreted to mean that locus of control relied on other factors such as academic self-efficacy to influence students' academic achievement. These disagreements call for further studies, especially for Physics, which is the area of concern of this study and the reason for this research.

\section{Study Habit}

Study is the activity that precipitates learning and gaining knowledge, either from books or by examining things in the world. Effective study habit, on the other hand, requires that learners studies regularly to achieve maximum success in their schoolwork (Ogbodo 2010). Fielden (2004) in Mendezabal (2013) observed that good study habits enable the student to critically reflect on skills outcomes such as selecting, analysing, critiquing, and synthesizing. Adeyemo (2010) considers study habit as a well-planned and deliberate form of reliability that the student adopts to understand any academic subject. Students with good study habits are able to evaluate the learning that have been achieved in order to make adjustments to whatever deficiency they experience (Nneji 2002). Successful students show a commitment to maximize learning from educational experiences, monitor their progress, and make adjustments in their efforts when necessary to accomplish their goal. An effective study habit is a behaviour embraced by students which serves as the vehicle of learning; it describes the degree to which the student engages in regular acts of studying, characterized by appropriate studying routines, including reviews of material, frequency of studying sessions, time management etc., occurring in a conducive environment (Mendezabal 2013). Study habit has been found to be closely related to academic achievement.

Some studies that examined the role of non-cognitive variables like study skills in academic achievement have affirmed their strong relationship with academic performance of students. A good study habit is thus important for academic success, especially in a technical subject like physics where more time, dedication and energy are needed to decode the technicalities, terminologies and the abstract nature of the subject. In a study that examined the usefulness of instilling good study habits in students as a means of enhancing their academic performance, Osa-Edoh and Alutu (2012) found significant relationship between the two variables. His study suggests that it is only when students cultivate proper study habits that their academic performance can be improved upon. A study by Olatoye (2008) identified students' study habits as main contributing factor in the prediction of physics achievement. 
His study implies that negative study habits is likely associated with student lack of impetus to engage adequately in productive physics learning during allocated school time and during personal study time.

A study by Mendezabal (2013) on students' performance in Philippine Professional Regulatory Commission's licensure examinations by revealed significant positive relationship between study habits of students and their academic achievement. The study indicated that high achievers have better study habits than the low achievers. Students who acquired better study habits scores have better performance in the licensure examination. A similar study by Mahwish, Naima, Hira and Wajiha (2017) on the performance of selected students of Allana Iqbal College for Women, Sailkot and Government Technical College for boys, Sailkot, Pakistan, also established a significant relationship between study habits and academic performance of the students.

Kalaivani and Babu (2013) studied the success of selected higher secondary school students of Cuddalore District, India in chemistry final exam compared with their study habits. The T-test that was performed for differences showed a directly proportional relationship between study habits and marks obtained in chemistry by the students. This indicates that students who followed a methodological study routine performed better in the examination.

However, there are investigations on study habits and performance that have posted negative results. Nouhi, Shakoori and Nakhei (2008) in their study on study habits, skills and academic achievement of students in Kerman University of Medical Sciences, Iran, found no relationship between study habits and students' academic achievement. Fakeye and Amao (2013) study, "Classroom Participation and Study Habit as Predictors of Achievement in Literature-in-English in selected senior secondary school in Ibadan North Local Government Area of Oyo State", concluded that student study habit had no significant relationship with their achievement in Literature-in-English $(\mathrm{r}=-.042, \mathrm{df}=498 ; \mathrm{P}<.05)$. This contrasting finding could be due to the nature of the subject of interest in this study, that is Literature-in-English rather than Physics. The result of this study could imply that it is possible for students to prepare and perform well in English language examination without following any particular study routine/habit. This finding is very significant as it provided evidence for more study on the relationship between study habits and academic achievement of students in other disciplines and population. 


\section{Gender}

Researchers hold contradictory opinions on whether there are gender differences in students' performance in sciences (Aina, 2013). Aweriale's (2006) study produced a conclusion that gender has no influence on performance in physics when the male and female are taught under the same conditions. The current study agrees with Aina and Aweriale that there is no gender difference in the academic achievement of senior secondary school students. Female students have shown that they are equal with their male peers in academic exercises when equal opportunity to compete are provided. Dania (2014) cited in Dania and Daniel (2015) also found no significant relationship between gender and students' academic achievement

According to the US National Science Foundation (2015) cited in Jugovic (2017), girls and women are not well represented in educational and career paths in Science, Technology, Engineering and Mathematics (STEM). The study by Jugovic (2017) shows that in the 2016/2017 school year, for instance, girls accounted for only $0.1 \%$ of admissions into secondary vocational schools for naval architecture in Croatia, 2.4\% in schools for mechanical engineering, 3.5\% in schools for electrical engineering, and $29.1 \%$ in schools for civil engineering. Similar statistics was reported in UK by Mujtaba and Reiss (2012). The study revealed that boys reported enjoying physics lessons more and found physics more interesting than the girls. The study opined that boys are more likely to report that they are good in physics than the girls. Similar studies have identified a predisposition to view STEM related subjects such as physics as subjects designated for boys and men. For instance, Francis, Archer, Moote, DeWitt, MacLeod, and Yeomans (2017) referenced studies showing that students perceive physics as a masculine subject. A study of selected students in Akwanga Local Government Area of Nasarawa State, Nigeria by Odagboyi (2015) revealed that the mean score of students' academic achievement in Biology favoured the males. This is a disturbing situation which requires attention and further examination. Corroborating the findings on gender disparity in STEM education, Seyranian, Madva, Duong, Abramzon, Tibbetts and Harackiewiz (2018) found evidence of gender disparity among students offering physics as a course. The study concludes that gender disparities in physics both in terms of belonging and physics knowledge is a serious situation. 


\section{Statement of the Problem}

The poor achievement of Nigerian students in Physics poses great challenge to national development and is a concern to physics education. Many factors have been adduced to be responsible for this trend and they could be grouped under teacher, school, government, home and student factors. Most studies focused on teacher and material variables affecting the teaching and learning of physics. There is dearth of literature in the area of student variables affecting the academic achievement of students' in Physics. Hence, the need for this study on the relationship between Locus of Control, Study Habit, Gender and Academic Achievement of senior secondary school Physics students in Ibadan metropolis, Oyo State, Nigeria.

\section{Research Questions}

1. What is the composite contribution of independent variables (locus of control, study habits and gender) to the dependent variable (academic achievement)?

2. What is the relative contribution of the independent variables (locus of control, study habits and gender) to the dependent variable (academic achievement)?

\section{Methodology}

The study adopted descriptive survey research design of the correlational type. The design is suitable because it enabled the researcher to examine the relationship between variables in the research study and to express the strength and direction of the relationship. This design cannot establish causality or time sequence because the events had taken place, but it can provide a good rationale for examining the predictive effects of one variable over the other. The aim was to examine the relationship between the independent variables and the dependent variable.

\section{Research Instruments}

Three research instruments were used for the study, Study Habits (SHQ), Locus of Control Scale (LOCS) and Physics Attitude Test Questionnaire. Sample of the instruments are attached in appendix section of this study. The design, validity and reliability were carried out as follows: 
Locus of Control Scale (LOCS): This scale was adapted from Terry Pettijohn's 20 item Locus of Control Scale published by Yemen and Clawson (2003) and reorganized to match the level of understanding of the sample population. The Locus of Control Scale LOCS contains 12 items. The instrument was used to find students' locus of control for learning of physics. The students responded by expressing their level of agreement or disagreement on a 4-point Likert-scale questions ranging from Strongly Disagree (SD), Disagree (D), Agree (A) to Strongly Agree (SA).

To ascertain the validity of the instrument, copies of LOCS was given to experts in the field of science education and education psychology to establish both face and content validity. The experts passed their comments on it and made necessary corrections. The instrument, which contained 48 questions, was taken for pilot study and was trimmed down to 12 questions after its the validation. The reliability of the instrument was determined using Cronbach's alpha and it was determined to be 0.86 .

Study Habit Questionnaire (SHQ): This scale was adapted from Virginia Gordon's University Survey: A guidebook and Readings for New Students. The instrument contained 20 items covering four variables, which was used to assess the study habit of senior secondary school students. The students responded by expressing their level of agreement or disagreement on a 4-point Likert-scale questions ranging from Strongly Disagree (SD), Disagree (D), Agree (A) and Strongly Agree (SA).

Copies of SHQ were given to experts in the field of science education and education psychology to establish both face and content validity. The experts passed comments on it and made necessary corrections. The instrument, which contained 48 questions, was taken for pilot study and was trimmed down to 12 questions after its the validation The reliability of the instrument was determined using Cronbach's alpha. The reliability of the instrument was determined to be 0.89 .

Physics Achievement Test (PAT): This scale was designed by the researcher to enable him assess students' physics content knowledge. The PAT was divided into two sections, section A and Section B. Section A contains the demographic data of the students, which include name of school, gender (sex), class and age. Section B contains multiple-choice questions examining student achievement in Physics. The PAT contains 20 multiple-choice questions with four response options A-D, constructed with table of specification on some selected topics in physics. Topics on which the test was based were Energy, Waves, Scalars and Vectors, Machines, Temperature and Measurement, Motion, and Linear Momentum. 
Copies of the PAT were given to experts in the field of science education to establish both face and content validity. The experts passed their comments and made necessary corrections. The instrument initially contained 50 questions which were trimmed down to 20 questions after the difficulty index and discrimination index had been ascertained from the result obtained during pilot study.

Data collected from the sampled population was analysed using inferential statistics of t-test and multiple regression analysis. These data packages enabled the researcher to examine the level of relationship existing between the variables in the study. The composite relationship between Locus of Control, Gender and, Academic Achievement was investigated using multiple regression analysis.

\section{Table 2 Specification of Items for topics used in the study}

\begin{tabular}{|c|c|c|c|c|c|c|c|}
\hline CONTENT & $\begin{array}{l}\text { PSYCHOLOGICAL } \\
\text { SKILLS }\end{array}$ & & & & & & \\
\hline & 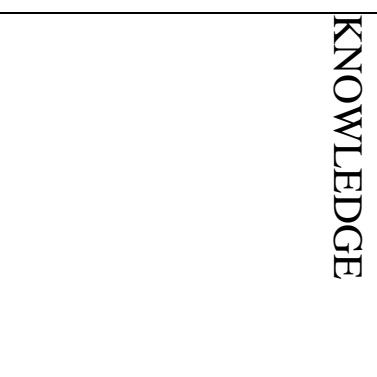 & 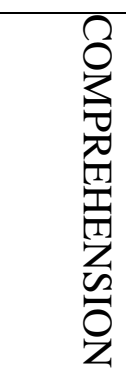 & 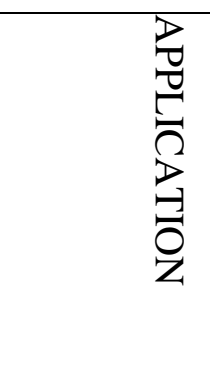 & $\underset{\sim}{Z} \underset{\sim}{Z}$ & 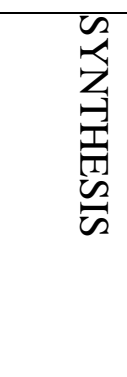 & 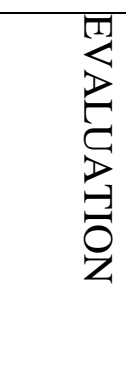 & 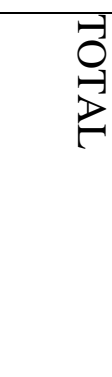 \\
\hline ENERGY & - & & - & - & - & $\begin{array}{l}7 \\
(1)\end{array}$ & 1 \\
\hline WAVES & ${ }^{15}(1)$ & - & - & - & - & - & 1 \\
\hline $\begin{array}{l}\text { SCALARS AND } \\
\text { VECTORS }\end{array}$ & & & $\begin{array}{l}11, \\
(1)\end{array}$ & - & & - & 1 \\
\hline MACHINES & - & ${ }^{8}(1)$ & $\begin{array}{l}9,16,17,18,19,20 \\
(6)\end{array}$ & - & - & - & 7 \\
\hline
\end{tabular}


The Influence of Locus of Control, Study Habits and Gender on the Academic Achievement of Senior Secondary School Physics Students in Ibadan Metropolis

\begin{tabular}{|l|l|l|l|l|l|l|l|}
\hline $\begin{array}{l}\text { TEMPERATURE } \\
\text { AND } \\
\text { MEASUREMENT }\end{array}$ & ${ }^{10}(1)$ & & - & - & - & - & 1 \\
\hline MOTION & - & ${ }^{2}(1)$ & 6 & $\begin{array}{l}13,14 \\
(2)\end{array}$ & - & 3,12 & 6 \\
\hline $\begin{array}{l}\text { LINEAR } \\
\text { MOMENTUM }\end{array}$ & $(1)$ & $2(1)$ & 5 & - & - & - & 3 \\
\hline TOTAL & 3 & $(1)$ & $(1)$ & & & & \\
\hline
\end{tabular}

Note: The numbers in bracket represents the number of items in each cell, while the subscripts represent the serial number of the item in PAT.

\section{Result and Discussions}

1. What is the composite contribution of independent variables (locus of control, study habits and gender) to the dependent variable (academic achievement)?

Table 3 Summary of Multiple Regression Analysis on composite the contributions of Independent Variables (locus of control, study habits and gender) to students' Academic Achievement

\begin{tabular}{|l|l|l|l|l|l|}
\hline Model & Sum of Square & Df & Mean Square & F & Sig \\
\hline Regression & 26.548 & 3 & 8.849 & .862 & $.460^{\mathrm{b}}$ \\
Residual & 7626.315 & 743 & 10.264 & & \\
Total & 7652.863 & 746 & & & \\
\hline $\mathrm{R}=.203$ & & & & \\
$\mathrm{R}^{2}=.041$ &
\end{tabular}


Adjusted $\mathrm{R}^{2}=.037$

Std. Error of the estimate $=3.14317$

Table 3 above reveals that the model (Locus of control, Gender and Study Habit) when taken together was unable to predict the dependent variable (Academic Achievement, measured in PAT), $[\mathrm{F}(3,746)=$ $0.862, \mathrm{P}<0.01$ ], with $\mathrm{R}=.203$, which is equivalent to $20.3 \%$. The variance, $\mathrm{R}^{2}=.041$, which is equivalent to $4.1 \%$, indicates a very poor level of shared variance between the dependent variable and the independent variable. This explains that $4 \%$ of the academic achievement of students in physics can be explained by the independent variables while the remaining $95.9 \%$ will be explained by factors not included in the study. This signifies a very poor relationship between the joint interaction of locus of control, gender, study habits and, academic achievement.

2. What is the relative contribution of the independent variables (locus of control, study habits and gender) to the depended variable (academic achievement)?

Table 4 Summary of the Multiple Regression Analysis showing Relative the contribution of Independent Variables (locus of control, study habits and gender) to Students' Academic Achievement

\begin{tabular}{|c|c|c|c|c|c|c|}
\hline \multirow[b]{2}{*}{ Model } & \multicolumn{2}{|c|}{$\begin{array}{l}\text { Unstandardized } \\
\text { coefficients }\end{array}$} & \multirow{2}{*}{$\begin{array}{l}\text { Standardized } \\
\text { coefficients } \\
\text { Beta (B) }\end{array}$} & \multirow[b]{2}{*}{ Rank } & \multirow[b]{2}{*}{$\mathrm{T}$} & \multirow[b]{2}{*}{ Sig } \\
\hline & $\begin{array}{l}\text { Beta } \\
(\beta)\end{array}$ & $\begin{array}{l}\text { Std. } \\
\text { Error }\end{array}$ & & & & \\
\hline (Constant) & 3.760 & 1.388 & & & 2.710 & .007 \\
\hline $\begin{array}{l}\text { Locus of } \\
\text { Control }\end{array}$ & .168 & .032 & .206 & $1^{\text {st }}$ & 5.310 & .000 \\
\hline $\begin{array}{l}\text { Study } \\
\text { Habits }\end{array}$ & -.015 & .018 & -.033 & $3^{\text {rd }}$ & -.854 & .394 \\
\hline Gender & $\begin{array}{l}-054 \\
-.054\end{array}$ & .242 & $\begin{array}{l}.008 \\
\end{array}$ & $2^{\text {nd }}$ & -.223 & .823 \\
\hline
\end{tabular}


Table 4 above presents the statistics of the relative contribution of the independent variables to the dependent variable when other variables are held constant. The most significant independent variable is Locus of Control, with unstandardized coefficient $(\beta)$ of 0.168 and standardized coefficient (B) of 0.206. This means that for one unit increase in locus of control, there will be an increase in students' academic achievement by 0.168 units. For the standardized coefficient, a unit deviation in locus of control will yield 0.206 deviations in students' academic achievement. The least significant contributor is Study Habits, with unstandardized coefficient $(\beta)$ of -0.054 and standardized coefficient $(\beta)$ of -0.008 . The result obtained shows no correlation between study habits and students' academic achievement in Physics. Gender, with unstandardized coefficient $(\beta)$ of -.015 and standardized coefficient (B) of -.008, is the second most significant contributor.

Table 5: Comparison of academic achievement of male and female physics students Group Statistics

\begin{tabular}{|l|l|l|l|l|l|}
\hline & Gender & $\mathrm{N}$ & Mean & Std. Deviation & Std. Error Mean \\
\hline \multirow{2}{*}{ PAT SCORE } & Male & 381 & 8.8451 & 3.35679 & .17197 \\
\cline { 2 - 6 } & Female & 369 & 8.5881 & 3.03485 & .15799 \\
\hline
\end{tabular}

Table 5 above shows the result of an independent-samples T-test which was carried out to compare the Physics Achievement Test score of male and female students. Result shows that the male students have the highest adjusted mean score $(\ddot{X}=8.85)$ while the female students have adjusted mean score $(\ddot{X}=8.59)$. But their mean difference is not statistically significant. The magnitude of the difference in the mean of the score was very small $($ Eta square $=0.0016)$

The finding of this study is in line with Nejati, Abedi, Agbaci and Mohammadi (2012) who investigated the relationship between locus of control and the academic performance of selected students of Azad Islamic University of Yazd, Iran, by considering the role quality of life and satisfaction with life. The outcome of the study by Nejati et al revealed that locus of control significantly correlated with the academic performance of the students. Also, these findings corroborate the findings of Samayalangki and Yodida (2017) which found that there was a strong 
positive correlation between internal locus of control and academic achievement among college students in Meghalay, India, from different streams, of both genders. The study found that there was a moderate positive correlation between external locus of control and academic achievement among the students. Findings of this study is contrary to findings of studies conducted by Reynolds and Weigand (2010), Dinçyürek, Güneyli, and Çaglar (2012) and Oludipe (2013) which found no significant relationship between locus of control and academic achievement of students. This could be as a result of more of the students having external locus of control or it could be that the instruments used for data collection in these studies were externally worded. However, these findings offered new dimension to the views of studies which found significant relationship between locus of control and students' academic achievement.

Result obtained from the study revealed that there is no significant relationship between study habits and academic achievement. Mendezabal (2013) found similar result. The study by Mendezabal (2013) shows that the students did not possess a favourable study habit. However, this is contrary to the findings of Mahwish, Naima, Hira and Wajiha (2017) on the performance of selected students in Sailkot, Pakistan, which found that there is significant relationship between study habits and academic performance of the students. The finding of the current study is contrary to the findings of Nouhi, Shakoori and Nakhei (2008) and Fakeye and Amao (2013) which found no significant relationship between study habits and students' academic achievement. The result of the study by Fakeye and Amao (2013) could imply that it is possible for students to prepare and perform well in English language examination without following any particular study routine/habit. This finding is very significant as it provided evidence for the relationship between study habits and academic achievement of students in other disciplines and population

The current study also discovers no relationship between gender and academic achievement of students. This is in line with Aweriale (2006) who also did not observe gender having an influence on performance in physics when the male and female are taught under the same conditions.

\section{Conclusion}

The following conclusions were made based on the findings from the study: 
The Influence of Locus of Control, Study Habits and Gender on the Academic Achievement of Senior Secondary School Physics Students in Ibadan Metropolis

1. There is a significant relationship between locus of control and academic achievement of the students in Physics. Students who recorded high locus of control scores equally recorded good achievement in physics test. This shows the importance of locus of control to students' academic achievement. It implies that for students to perform well in Physics, positive locus of control is needed. Hence, there is need to assist students to develop good locus of control.

2. There is no significant relationship between the study habits of the students and academic achievement. Students with low study habits achieved poor scores in Physics test.

3. There is no significant relationship between gender and academic achievement. Male students did not perform better than the female students. There is no significant difference between the scores of the male and female students in the Physics test.

4. The study also found out that the variables (locus of control, study habits and gender) when taken together was able to predict academic achievement of students. The level of shared variance is positive, though quite poor. This shows that the independent variables when taken together can exert a level of influence on the academic achievement of students.

\section{Recommendations}

The study therefore recommends the adoption of the necessary instructional methods that will enhance students' locus of control. Such instructional method should be the type that will avail students the opportunity to take on exercises/ assignments and individual task. The study also recommends that in order to help the students to be more successful in life, Internal Locus of Control needs to be encouraged among students. This will motivate students to work harder for their progress with the believe that they are responsible for their own success or failure

The study recommends that stereotypical association of Physics with the male gender be discouraged in Physics classes. Also, female students should be given equal chance to play active role in physics classes

Governments, education administrators and school authorities should consider the joint interactive influence of locus of control, study habits and gender when designing programs for physics. 


\section{Reference}

Adeyemo, S. A. (2010). Teaching/Learning of Physics in Nigerian Secondary Schools: The Curriculum Transformation Issues, Problems and Prospects. International Journal of Educational Research and Technology, Vol 1(1), June 2010: 99-111

Aina, J. K. (2013). Gender Analysis of Students' Academic Performance in Physics Practical in Colleges of Education, Nigeria. Advances in Arts, Social Sciences and Education Research. (C) Science and Education Development Institute, 2013 Volume 3 (5) May: 447 452, ISSN: 2276 - 6715 http://www.ejournal.sedinst.com. Accessed Thursday, April 23, 2015, 2:41:29 PM

Aweriale, P.E.O. (2006). Gender performance in physics: A case study in Auchi Polytechnic, Auchi. Nigeria Journal of Professional Teachers 1 (2), 223-234

Awofala, A.O.A; Awofala, A.A.; Fatade, A.O. and Nneji, L.M.(2012). Determinants of students' achievement in senior secondary school mathematics and sciences: What is the role of Test Response Mode and Locus of control? International Journal of Mathematics Trends and Technology, 3(3), 125-130

Azlina, M. K , Ma'rof,R., Hanina H. H. and Mohd Ibrani, S. (2015). Locus of Control and Academic Achievement among Orang Asli Students in Malaysia. Available from: https://www.researchgate.net/publication/319346344_Locus_of_Control_and_Academic Achievement_among_Orang_Asli_Students_in_Malaysia [accessed Nov 25 2019].

Dania, C. M. and Daniel, F. (2015). Influence of Subject Combination and Gender on Achievement of NCE Physics Students in Physics. International Journal of Social Science and Humanities Research. 3(1), 169 - 174. Available at: www.researchpublish.com

Dinçyürek, S, Güneyli, A. \& Ça $\div$ lar, M. (2012). The Relation between Assertiveness Levels, Locus of Control and Academic Success of Turkish Language Teacher Candidates, Sociology Mind, 2(1), 61-66.

Fajonyomi, A. A. (2007). Reviving higher education relevance in Nigeria. A paper presented at the 3rd Faculty of Week and Annual National Conference, Faculty of Education. University of Maiduguri on the theme Higher education reforms in Nigeria from 26th to 27th September. 
Fakeye, D. O. and Amao, T. A. (2013). Classroom Participation and Study Habit as Predictors of Achievement in Literature-in-English. Cross-Cultural Communication, 9(3), 18-25. Available from: http//www.cscanada.net/index.php/ccc/article/view/j.ccc.1923670020130903.2741 DOI: http://dx.doi.org/10.3968/j.ccc.1923670020130903.2741. Accessed Tuesday, November 10, 2015, 2:21:19 PM

Fakeye, D. O. (2011). Locus of Control as a Correlate of Achievement in English Language in Ibadan. The Journal of International Social Research. Cilt: 4 Say1: 17 Volume: 4 Issue: 17. Bahar 2011, Spring 2011

Francis, F., Archer, L., Moote, J., DeWitt, J., MacLeod, E., and Yeomans, L. (2017). The Construction of Physics as a Quintessentially Masculine Subject: Young People's Perceptions of Gender Issues in Access to Physics. Sex Roles, 76(3), 156-174.

Jugovic, I. (2017). Students' Gender-Related Choices and Achievement in Physics. c e p s Journal $7(2)^{\prime} 71-95$

Kalaivani, S. and Badu, R. (2013). Higher Secondary Students Achievement in Chemistry Relation to their Study Habits. International Journal of Current Research

Mahwish, R., Naima, M., Hira, T. and Wajiha, N. (2017). A Study on Study Habits and Academic Performance of Students. International Journal of Asian Social Science. Accessed November 24, 2019 from https://www.researchgate.net/publication/322206720_A_Study_on_Study_Habits_and_Ac ademic_Performance_of_Students

Mendezabal, M. J. N. (2013). Study Habits and Attitudes: The Road to Academic Success. Open Science Repository Education, Online (open-access) e70081928. doi:

10.7392/education.70081928

Mujtaba, T., and Reiss, M. J. (2013). What sort of girl wants to study physics after the age of 16 ? Findings from a large-scale UK survey. International Journal of Science Education, 35(17), 2979-2998

Nejati, M., Abedi, A. A. and Mohammadi (2012). The Relationship between Locus of Control with the Academic Performance of the M.A. students by considering the role of life quality and satisfaction with life. Interdisciplinary Journal of Contemporary Research in Business, 4(5), 254-263. 
Nigerian Education Research and Development Council (2008). Senior Secondary School Physics Curriculum 1-3. ISBN 978-054-696-0.

Nneji, L. M. (2002). Study habits of Nigerian university students. Nigerian educational research and development council, Abuja, Nigeria.

Nouhi, E., Shakoori, A., and Nakhei, N. (2008). Study habits and skills, and academic achievement of students in Kerman University of medical sciences. Journal of Medicine Education Vol. $12(3,4) 77-80$.

Nuthana, P and Yenagi, G. 2009. Influence of study habits, self-concept on academic achievement of boys and girls. Karnataka J. Agric. Sci., 22 (5), 1135-1138

Odagboyi. I. A. (2015). The Effect of Gender on the Achievement of Students in Biology Using the Jigsaw Method. Journal of Education and Practice. 6(17); 176 - 180.

Ogbodo, R. O. (2010). Effective Study Habits in Educational Sector: Counseling Implications. Edo Journal of Counseling, Vol. 3(2)

Ogunmakin, A. O. and Akomolafe, M. J. 2013. Academic Self-Efficacy, Locus of Control and Academic Performance of Secondary School Students in Ondo State, Nigeria.

Mediterranean Journal of Social Sciences, Vol. 4(11), 570 -576.

Oludipe, B. D. (2013). Predicting Students' Achievement in Physics using Academic Self Concept and Locus of Control Scale Scores. International Journal of Social Science and Education. Vol. 3, issue 4, ISSN: 2223-4934E and 2227-393X print

Osa-Edoh, G. I. and Alutu, A. 2012. A Survey of Students' Study Habits in Selected Secondary Schools. Implication for Counseling. Current Research Journal of Social Sciences. Vol. 4(3), pg. 228-234

Reynolds, A. L., and Weigand, M. J. (2010). The relationships among academic attitudes, psychological attitudes, and the first-semester academic achievement of firstyear college students. Journal of Student Affairs Research and Practice, 47(2), 175-195.

Samayalangki, N. and Yodida, B. (2017). Locus of Control in Relation to Academic Achievement of College Students in Meghalaya. 4thInternational Conference on Multidisciplinary Research \& Practice (4ICMRP). Pp 159 - 166. Accessed Nov. 25, 2019 from WWW.rsisinternational.org

Sani, A. (2012). Role of Physics Education for Technological Development, Employment and Self Productivity in Nigeria. Journal of Education and Social Research, Vol. 2(10), pg 166 
The Influence of Locus of Control, Study Habits and Gender on the Academic Achievement of Senior Secondary School Physics Students in Ibadan Metropolis

Seyranian, V., Madva, A., Duong, N., Abramzon, N., Tibbetts, Y. and HarackiewiZ, J. M. (2018). The longitudinal effects of STEM identity and gender on flourishing and achievement in college physics. International Journal of STEM Education. 5(40); 2 - 14.

Tucker, G. R, Hamayan, E. and Genesse, F.H. (2006). Affective, cognitive and social factors in second language acquisition, Canadian Modern Language Review, 32, 214-26.

Yang, D. H. (2010). Gender and classroom learning. Psychology in the Schools, 22, 08-2 


\section{APPENDIX A}

\section{STUDENTS' PHYSICS ACHIEVEMENT TEST}

Dear respondent,

This questionnaire is designed to elicit honest responses from the respondents and it is meant for students who are currently in SS3. In this regard, I solicit your honest answers to the questions below. The information obtained will be used purely for academic purpose.

Thanks for your anticipated cooperation.

SECTION A: (Tick appropriately and write were such spaces are provided)

Name of School:

Class/Level of Study: ....... SSS ( )

Age: $\quad$ Sex:

\section{SECTION B}

General Instruction: The test is designed to assess students' physics content knowledge. Options A - D has been provided, choose appropriately.

1. Impulse is :

a. the product of time and acceleration $\quad$ b. the effect of force on a body $\quad$ c. the product of force and time $\quad$ d. energy e. None of the above

2. Explain why the velocity of the gun is lower than that of the bullet shot out of the gun

a. Because the mass of the gun is bigger than that of the bullet shot out

b. Because, the gun has an internal processes

c. Because the bullet travels faster than the gun 
d. Because of the sound coming from the gun

e. None of the above

3. A car moving at $50 \mathrm{~km} / \mathrm{h}$ is justifying Newton's first law of motion.
a. True
b. False
c. Not sure
d. often
e. None of the options

4. The difference between weight and mass is

i. weight is a vector quantity while mass is a scalar quantity

ii. weight is a for of force

iii. Weight is same as mass
a. I
b. ii
c. iii
d. $i$ and ii
e. ii and iii

5. $\mathrm{I}=\mathrm{F} x \mathrm{t}$, where $\mathrm{I}=$ impulse of $\mathrm{a}$ body, $\mathrm{F}=$ force on the body, $\mathrm{t}=$ time. From this, impulse then means
a. force and time
b. the force acting on a body and the time during which it acts
c. force of time d. force acting on time e. time during which force acts

6. A resultant force of $50 \mathrm{~N}$ acts on a mass of $2.5 \mathrm{~kg}$, starting from rest. Calculate acceleration produced.
A. $20 \mathrm{~m} / \mathrm{s}^{2}$
b. $15 \mathrm{~m} / \mathrm{s}^{2}$
c. $18 \mathrm{~m} / \mathrm{s}^{2}$
d. $25 \mathrm{~m} / \mathrm{s}^{2}$
e. $50 \mathrm{~N}$

7. Distinguish kinetic and potential energies.

a. They are energies at work

b. P.E is due to position while K.E is energy as a result of its motion c. They are both in motions
d. All of the above
e. None of the above

8. Which of the following is not an example of levers of the first order?

a.
Crossbar
b. Nutcracker
c. Scissors
d. Plier
e. All of them

9. The velocity ratio of an inclined plane whose angle of inclination is $\mathrm{O}$ is

a. $\operatorname{Sin} \mathrm{O}^{\circ}$
b. $\operatorname{Cos} \mathrm{O}^{\circ}$
c. $1 / \sin \mathrm{O}^{\circ}$
d. $1 / \tan \mathrm{O}^{\circ}$
e. $1 / \cos \mathrm{O}^{\circ}$ 

10. W hat is the lowest fixed point on the Kelvin scale?
A. 0
b. 303
c. 273
d. 100
e. 173

11. Determine the resultant of two forces $5 \mathrm{~N}$ and $7 \mathrm{~N}$, acting on a body from a point if they act in $\begin{array}{llllll}\text { the same direction } & \text { a. } 2 \mathrm{~N} & \text { b. } 12 \mathrm{~N} & \text { c. } 35 \mathrm{~N} & \text { d. } 13 \mathrm{~N} & \text { e. }-2 \mathrm{~N}\end{array}$

12. A stone is thrown vertically upwards with an initial velocity $\mathrm{Um} / \mathrm{s}$. It reaches a maximum height and returns to the ground. Derive an expression the maximum height... a. $h=u^{2} / 2 g \quad b$. $\mathrm{h}=2 \mathrm{~g} / \mathrm{u}^{2} \quad$ c. $\mathrm{h}=\mathrm{u} / 2 \mathrm{~g} \quad \mathrm{~d} . \mathrm{h}=0 \quad$ e. $2 \mathrm{ug}$

13. Deduce the expression for the velocity acquired in a distance $S$, by a body which starts with a velocity $\mathrm{U}$ and moves with a uniform acceleration $\mathrm{A}$.
a. $v^{2}=u^{2}+2 a s$
b. $v=u+a t$
c. $v^{2}=u^{2}+2 g h$
$\mathrm{d} . \mathrm{v}=2 \mathrm{gh}$
e. $V=u t+2 a t^{2}$

14. Deduce the expression for the velocity acquired in a time $t$ for the body with initial velocity $u$ and uniformly accelerated a.
a. $v^{2}=u^{2}+2 a s$
b. $v=u+a t$
c. $v^{2}=u^{2}+2 g h$
$\mathrm{d} . \mathrm{v}=2 \mathrm{gh}$
e. $V=u t+2 a t^{2}$

15. Transverse wave is an example of.......
a. Progressive wave
b. Interference
c. Frequency
d. Longitudinal wave
e. wave on water

16. Two forces, whose resultant is $100 \mathrm{~N}$, are perpendicular to each other. If one of them makes an angle of $60^{\circ}$ with the resultant, calculate its magnitude:

$$
\left(\sin 60^{\circ}=0.8660, \cos 60^{\circ}=0.5000\right)
$$
a. $200.0 \mathrm{~N}$
b. $86.6 \mathrm{~N}$
c. $173.2 \mathrm{~N}$
d. $115.5 \mathrm{~N}$
e. $50 \mathrm{~N}$

17. A machine with a velocity ratio of 30 moves a load of $3000 \mathrm{~N}$ when an effort of $200 \mathrm{~N}$ is applied. The efficiency of the machine is
a. $30 \%$
b. $50 \%$
c. $60 \%$
d. $25 \%$
e. $40 \%$ 
The Influence of Locus of Control, Study Habits and Gender on the Academic Achievement of Senior Secondary School Physics Students in Ibadan Metropolis

18. The efficiency of a wheel and axle system is $80 \%$ and the radius of wheel to radius of axle is 4:1. In order to lift a mass of $20 \mathrm{~kg}$, the effort required is
a. $60 \mathrm{~N}$
b. $32.5 \mathrm{~N}$
c. $62.5 \mathrm{~N}$
d. $250 \mathrm{~N}$
e. $80 \mathrm{~N}$

19. A plane inclined at an angle $30^{\circ}$ to the horizontal has an efficiency of $60 \%$. The force parallel to the plane required to push a load of $120 \mathrm{~N}$ uniformly up the plane is ? $\begin{array}{lll}\text { a. } 60 \mathrm{~N} & \text { b. } 100 \mathrm{~N}\end{array}$
c. $120 \mathrm{~N}$
d. $200 \mathrm{~N}$
e. $140 \mathrm{~N}$

20. The velocity ratio of an inclined plane whose angle of inclination is $0^{\circ}$ is
a. $\operatorname{Sin} 0$
b. $\cos 0$
c. $\tan 0$
d. $1 / \cos 0$
e. $1 / \sin 0$ 


\section{APPENDIX B}

\section{Students' Questionnaire on Study Habit and Locus of Control Test}

General Instruction: The questions below are designed to assess the relationship between students' Study Habit. The response keys are SD = Strongly Disagree, D = Disagree, A = Agree, SA = Strongly Agree.

\begin{tabular}{|c|c|c|c|c|c|}
\hline S/No & Items & SD & $\mathrm{D}$ & $\mathrm{A}$ & SA \\
\hline & Time Management & & & & \\
\hline 1 & I make my personal study timetable for each term. & & & & \\
\hline 2 & $\begin{array}{l}\text { I reschedule the time table every week if I miss my } \\
\text { study time }\end{array}$ & & & & \\
\hline 3 & I study for at least 2 hours every night. & & & & \\
\hline 4 & $\begin{array}{l}\text { I stipulate my time for exercise and socialization with } \\
\text { my friends }\end{array}$ & & & & \\
\hline 5 & $\begin{array}{l}\text { I love spending enough time chatting and playing with } \\
\text { my friends. }\end{array}$ & & & & \\
\hline & Study Environment & & & & \\
\hline 6 & I have a special place that I go to read. & & & & \\
\hline 7 & $\begin{array}{l}\text { If the place I am staying to read is too quiet, I usually } \\
\text { feel sleepy }\end{array}$ & & & & \\
\hline 8 & $\begin{array}{l}\text { I cannot read in a noisy environment so I go to quiet } \\
\text { places to read. }\end{array}$ & & & & \\
\hline
\end{tabular}


The Influence of Locus of Control, Study Habits and Gender on the Academic Achievement of Senior Secondary School Physics Students in Ibadan Metropolis

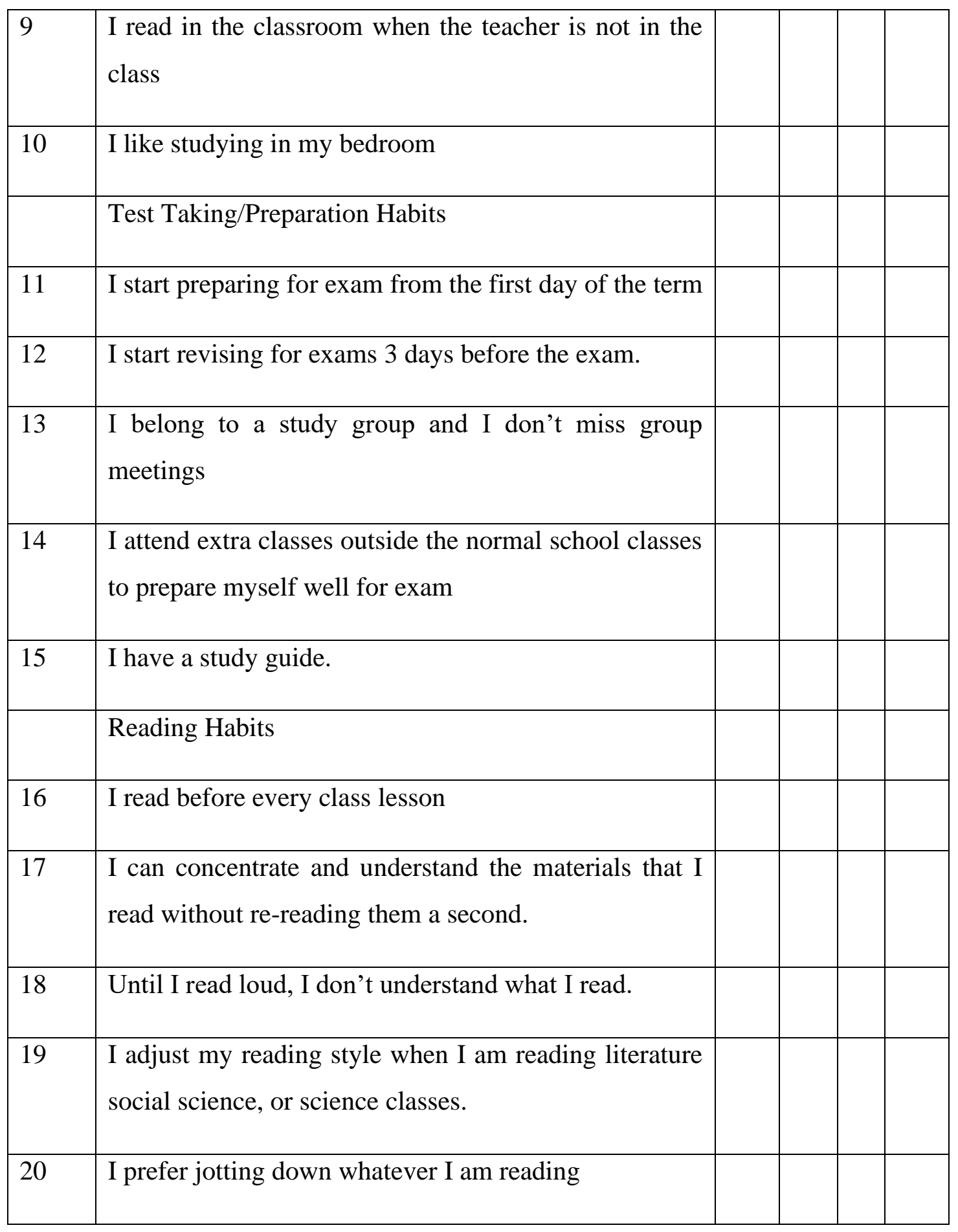

\section{Locus of Control Test}




\begin{tabular}{|c|c|c|c|c|c|}
\hline & Questions & SD & $\mathrm{D}$ & A & SA \\
\hline 1 & I usually get what I want in physics & & & & \\
\hline 2 & I don't really need luck to do well in physics & & & & \\
\hline 3 & If I don't succeed on a physics task, I tend to give up & & & & \\
\hline 4 & My success in physics is by chance & & & & \\
\hline 5 & Everybody must work hard to achieve success in physics & & & & \\
\hline 6 & I would not be doing physics if I am not sure of it & & & & \\
\hline 7 & I deserve the respect I receive from physics classmates & & & & \\
\hline 8 & People become successful in physics when they work hard & & & & \\
\hline 9 & Success in physics is by luck & & & & \\
\hline 10 & $\begin{array}{l}\text { Persistence and hard work usually lead to success in } \\
\text { physics }\end{array}$ & & & & \\
\hline 11 & $\begin{array}{l}\text { My physics teacher can pass or fail, depending on whether } \\
\text { he/she likes me }\end{array}$ & & & & \\
\hline 12 & I never knew where I stand with physics & & & & \\
\hline
\end{tabular}

